\title{
Comment
}

\section{The Triumph of European Union Law in International Investment Law - The Phenomenon, the Problems, and the Solution*}

I. The Relative Unknown versus the Muhammed Ali of the Law on International Responsibility

II. Doctrinal Problems with BayWa-Created Jurisprudence on Legitimate Expectations 887

III. Broader Implications of the BayWa-Created Jurisprudence on Legitimate

Expectations

IV. The Alternative Jurisprudence: Using Contributory Fault

V. Conclusion

\section{The Relative Unknown versus the Muhammed Ali of the Law on International Responsibility}

Many readers will know that the European Court of Justice has been active in profoundly changing international investment law in recent years. Most particularly, in the Achmea Decision, the European Court of Justice effectively interdicted the possibility of European Union-based investors from suing European Union Member States in investment-treaty arbitration, otherwise known as 'Investor-state Dispute Settlement (ISDS)'. ${ }^{1}$ Now it is the turn of European Union law to impose itself on international investment law. This comment shines a light on this under-the-radar, but critical, jurisprudential development, which comes from the recent case of BayWa v. Spain. ${ }^{2}$

\footnotetext{
* Senior Research Fellow, Max Planck Institute for Comparative Public Law and International Law.

1 This is a dispute settlement mechanism that allows foreign investors to file complaints against states for their (allegedly) unlawful actions that devalue investors' investments. Whether an action is unlawful or not is decided with reference to the 'investment protection standards' in the investment treaty that the investor uses to sue the state.

2 BayWa r.e. Renewable Energy GmbH and BayWa r.e. Asset Holding GmbH v. Spain, ICSID case no. ARB/15/16.
} 
The basic facts of this case can be summarised quickly. ${ }^{3}$ The investor invested in renewable-energy power plants. The production of the electricity was subsidised by Spain. When the Spanish financial crisis took hold, money became tight and the subsidy programme that the investor benefitted from was scaled back. The value of the investor's investment decreased. The investor claimed compensation on the ground that these changes frustrated its legitimate expectations because the original subsidy programme should have continued its operation.

The investor was successful in claiming some compensation, but, for the most part, its claim was unsuccessful. One reason for this lack of success was a novel argument that Spain deployed. That argument posited that because the treatment given to the investor (the subsidy payments) was illegal under Spanish domestic law (which includes European Union law), because Spain failed to notify the European Commission of such payments, the investor could not legitimately expect this treatment. The arbitral tribunal (by majority) accepted this argument.

During the traditional Referentenbesprechung of the Max Planck Institute for Comparative Public Law and International Law on Monday, 12 July 2021, the international validity of this argument was the subject of intense debate. The Referent (and author of this comment) concluded that it was problematic. Some researchers agreed, but the vast majority did not. They are in good company. The towering figure of James Crawford served as the president of the arbitral tribunal for BayWa v. Spain. On matters of international responsibility, James Crawford is the equivalent to $\mathrm{Mu}-$ hammed Ali, while the author is a relative unknown. But even Ali was not invincible. With great respect, it is considered that there is a better alternative to the new jurisprudence created by the arbitral tribunal in BayWa v. Spain. To get to that conclusion, the first step is to show the doctrinal problems with this jurisprudence (section 2). The second step proceeds to examine of the broader negative implications of this jurisprudence, before then noting that it does pursue an important policy-end (section 3). The third step is to put forward an alternative jurisprudence that not only pursues this policy-end, but also avoids the negative aspects of the new jurisprudence (section 4).

3 The case of BayWa $v$. Spain is one of many investment-treaty arbitrations that have recently been launched against Spain because of its actions against investors in renewableenergy power plants. For further background on these disputes, see Norah Gallagher, 'ECT and Renewable Energy Disputes' in: Maxi Scherer (ed.), International Arbitration in the Energy Sector (Oxford: Oxford University Press 2018). 


\section{Doctrinal Problems with BayWa-Created Jurisprudence on Legitimate Expectations}

Understanding the problems with the jurisprudence on legitimate expectations from BayWa v. Spain begins with examining the arbitral tribunal's legal reasoning. The most important part of this legal reasoning reads as follows: ${ }^{4}$

'In principle, an investor cannot have a legitimate expectation of treatment which is unlawful under the law of the host State, provided that the host State law itself is not inconsistent with the treaty under which the tribunal exercises its jurisdiction. In an international forum such as the present one, a host State may not rely on its domestic law as a ground for non-fulfilment of its international obligations. But subject to that qualification, investors must also comply with the law of the host State, both as regards their investment and their concomitant expectations.'

What is particularly interesting about this extract is that the arbitral tribunal mentions the rule that a state may not invoke its domestic law to avoid its international obligations, but does not apply it. This void ought to be filled. To do so, it is worth setting out this rule in full, as it is formulated in Article 3 of the Articles on State Responsibility: 5

'The characterization of an act of a State as internationally wrongful is governed by international law. Such characterization is not affected by the characterization of the same act as lawful by internal law.'

The basic import of this rule is that the determination of international responsibility is a matter only for international law. The commentary on this provision confirms this. As Crawford states in his canonical commentary on the Articles on State Responsibility: ${ }^{6}$

'It was established as long ago as the Alabama arbitration that a state may not rely on its own law as an excuse for failure to comply with its international obligations [...] The characterization of conduct as lawful or not is an autonomous function of international law. The long line of authorities supporting this proposition is surveyed in the commentary: they include the Wimbledon, the Reparations for Injuries opinion and the ELSI case.'

4 ICSID, BayWa r.e. Renewable Energy GmbH and BayWa r.e. Asset Holding GmbH v. Spain, Decision on Jurisdiction, Liability and Directions on Quantum of 2 December 2019, case no. ARB/15/16 ('BayWa $v$ Spain, award'), para. 569(a) (footnotes omitted).

5 A similar rule is found in Art. 27 Vienna Convention on the Law of Treaties.

6 James Crawford, State Responsibility: The General Part (Cambridge: Cambridge University Press 2013), 101. 
The question is now: how does the Spanish argument infringe on the rule in Article 3? The answer comprises two premises. The first is uncontroversial: for a state to frustrate a 'legitimate expectation', noting that such frustration gives rise to international responsibility under fair-equitable-and-treatment clauses in investment treaties, a necessary pre-requisite is that the investor proves the existence of a legally recognisable legitimate expectation. The second premise focuses on the nature of the Spanish argument. That argument claims that the treatment that is the subject of a legitimate expectation can only be 'legitimate' if such treatment is legal under host state law. Effectively, with this argument, Spain is defining the content of 'legitimate' in legitimate expectations with reference to domestic law. Putting these two premises together, what they practically mean is that when an arbitral tribunal is determining the question of international responsibility for alleged frustration of legitimate expectations, it has to first decide if there is a 'legitimate expectation' and, to make that determination, it should consult domestic law. If, according to domestic law, the treatment that is the subject of the putative legitimate expectation is illegal, then this putative legitimate expectation does not qualify as a 'legitimate expectation'. Naturally, this means that the investor's claim will fail, thereby meaning that the state avoids international responsibility. This process of legal reasoning constitutes a prima facie infringement of Article 3.

But this is not the end of the matter. As Crawford notes in his commentary, there is a way to circumvent the rule contained in Article 3 and exceptions must be made to this rule, particularly in investment-treaty arbitration. ${ }^{7}$ The way to circumvent it is with the rule that domestic law may be used as a fact when determining international responsibility. ${ }^{8}$ Most typically, when using domestic law as a fact, it is held up against an international rule and its compliance with that rule is assessed. For example, if an investor in an investment-treaty arbitration claims that a domestic law has had the effect of expropriating its investment, the arbitral tribunal will have the task of determining, as a matter of fact, how that domestic law actually operates, before then asking: does this operation amount to expropriation as per the doctrine from international law? This is not what happened in BayWa v. Spain. There, the arbitral tribunal did not measure Spanish domestic law against an international rule (fair and equitable treatment), but rather decided that domestic law could define a concept in this international rule.

7 Crawford (n. 6), 101.

8 See generally Jarrod Hepburn, 'Domestic Law in International Adjudication' in: Hélène Ruiz Fabri (ed.), Max Planck Encyclopedia of International Procedural Law (online edn, Oxford: Oxford University Press 2019). 
For this reason, the new doctrine in BayWa v. Spain should be seen as an exception to the rule in Article 3. It would not be the first in international investment law. Another example concerns the nationality requirement. The specifics of this requirement vary from treaty to treaty, but, generally speaking, ${ }^{9}$ it stipulates that investors, if they are natural persons, must be citizens of or, if they are companies, must be incorporated in a treaty party other than the respondent state. Whether an investor holds such citizenship or is so incorporated is a question that is determined with reference to the laws of its putative home state. Accordingly, the nationality requirement is defined by domestic law, which also is the case with legitimate expectations as per the doctrine enunciated in BayWa v. Spain.

But there is a crucial distinction here: the nationality requirement-related exception has rock-solid doctrinal foundations because investment treaties explicitly or implicitly stipulate that arbitral tribunals must apply domestic law. ${ }^{10}$ Locating the doctrinal foundations for an exception with respect to legitimate expectations is more difficult. The arbitral tribunal pointed to other arbitral awards that allegedly supported this exception, ${ }^{11}$ although, having read these arbitral awards, that support is not apparent. Still, some doctrinal foundations might be constructed. The first plank that can be laid in this construction is the following: domestic law will invariably be one of the governing laws that an arbitral tribunal may apply in an investment-treaty arbitration, as was the case in BayWa v. Spain. ${ }^{12}$ But arbitral tribunals cannot apply domestic law at will. They have to apply it in a manner that respects the pre-eminence of international law in investment-treaty arbitrations. ${ }^{13}$ For an arbitral tribunal that seeks to confirm the jurisprudence from BayWa v. Spain, what this rule means is that it has to recruit some international rules and use them to define 'legitimate expectations' with reference to domestic law. The best candidates for this role are the rules on treaty interpretation. With the help of these rules, an arbitral tribunal can take a fair-equitable-andtreatment clause and put together an argument to the effect that 'treatment'

9 Rudolf Dolzer and Christoph Schreuer, Principles of International Investment Law (Oxford: Oxford University Press 2012), 97-99.

10 Borzu Sabahi, Noah Rubins, and Don Wallace, Jr., Investor-State Arbitration (2nd ed., Oxford: Oxford University Press), paras 11.12 and 11.14.

11 BayWa v. Spain, award, fn. 778.

12 BayWa v. Spain was an investment-treaty arbitration filed under the ICSID Convention. Under the ICSID Convention, arbitral tribunals are authorised to apply the domestic law of the host state to resolve the dispute, see Art. 42(1) Convention on the Settlement of Investment Disputes between States and Nationals of Other States.

13 This is known as the 'Wena Doctrine' in international investment law. For an overview of this doctrine, see Hege Elisabeth Kjos, Applicable Law in Investor-State Arbitration (Oxford: Oxford University Press 2013), 224-240. 
means only 'treatment in accordance with the host state law existing at the time of the investment'. The various premises of this argument will not be detailed here, but it is considered that this argument could be a very respectable one, particularly remembering that treaty text must be interpreted with regard to its object and purpose. A strong case could be made that the object and purpose of a fair-and-equitable-treatment clause would be defeated if the investor could use it to claim compensation for denial of treatment that is illegal under domestic law.

\section{Broader Implications of the BayWa-Created Jurisprudence on Legitimate Expectations}

But more than one can play the game of teleological interpretation. Specifically, if a fair-equitable-and-treatment clause is interpreted with reference to domestic law, then its legal integrity can be compromised. This point can be best understood with an example. For this purpose, imagine a case similar to BayWa v. Spain, although, in this case, there are questions about the material validity of the subsidy programme that the investor benefits from. These questions are ignored for years and the investor happily takes the subsidies. After some years, paying the subsidies becomes financially inconvenient for the state, and it looks to stop it. It is wary that that course of action could result in international responsibility under its investment treaties. Some lawyers for the state hatch a plan. They decide that a state-owned company should bring an action against the investor for receiving illegal subsidies. After the (biased) judges find in favour of the state-owned company, the state has the excuse to, one, deny the investor the treatment that it benefits from, and, in light of the doctrine from BayWa v. Spain, two, avoid international responsibility. With this process, the state has effectively compromised the integrity of one of its international obligations, namely the rule to treat investments fairly and equitably. Is this what happened in BayWa v. Spain? No. But could it happen in the future? Yes, because when the legal content of international legal concepts is determined by domestic law, international adjudicators put themselves at the mercy of domestic institutions, particularly domestic courts given their role in clarifying the content of domestic law.

There is another more practical aspect of the jurisprudence from $\mathrm{Bay} W a$ v. Spain that is problematic. The key factor for this purpose was that Spain did not change the subsidy programme that the investor benefitted from because of its invalidity under European Union law (which is part of Spanish 
domestic law). The real reason that prompted Spain to act was the Spanish financial crisis. As noted by the dissenting arbitrator, Spain's argument that the subsidy was illegal under European Union law was only brought up in the context of the arbitration, a fact that prompted him to describe it as an opportunistic argument. ${ }^{14}$ This is what this new jurisprudence allows. And because of this, in future investment-treaty arbitrations where the state is alleged to have frustrated an investor's legitimate expectations, counsel for the state will be pushing forward any possible argument that the treatment that was expected was illegal, a task, for example, that might be made easier by a (biased) domestic court giving a legal opinion to the effect that it indeed was illegal.

Despite these points in favour of strictly applying the rule in Article 3, it has to be admitted that there are cases where it will be unacceptable to allow the investor to succeed. Consider a case of an investor who owns a nuclear power plant. In complete defiance of domestic law, a government minister represents to the investor that its power plant will not be the subject of annual safety tests, which in turn saves the investor multiple costs. A new government takes power. It is committed to the rule of law. It starts annual safety tests and the investor sues in investment-treaty arbitration. No arbitral tribunal will let this claim succeed. Considering that the non-performance of the annual safety test amounted to a flagrant breach of domestic law, it was never going to continue, particularly once a rule of law-dedicated government took power. This is a point that the arbitral tribunal for BayWa v. Spain made in its reasoning: ${ }^{15}$ the investor should have been on notice that there were legal problems with the subsidy programme. It emphasised that European Union law was clear: if a subsidy is not notified to the European Commission, then it is unlawful. And not only is this law clear, but it is a basic rule of European Union state aid law, meaning that any investor should know about it.

\section{The Alternative Jurisprudence: Using Contributory Fault}

An impasse has been reached. The new jurisprudence from BayWa v. Spain rightly prevents investors from claiming compensation in circum-

14 ICSID, BayWa r.e. Renewable Energy GmbH and BayWa r.e. Asset Holding GmbH v. Spain, Dissenting Opinion (Horacio A. Grigera Naón) of 2 December 2019, case no. ARB/ 15/16, para. 36.

15 BayWa v. Spain, award, para. 569(b). 
stances where it is clear that the treatment that it benefits from is illegal, but, equally, it potentially undermines the integrity of fair-equitable-and-treatment clauses and allows states to put forward opportunistic arguments to avoid international responsibility under these clauses. The challenge is to put forward alternative jurisprudence that takes account of these concerns, while also simultaneously respecting the established doctrine of international law.

The tool to produce that alternative jurisprudence is contributory fault. Contributory fault finds its doctrinal foundations in Article 39 of the Articles on State Responsibility. Very concisely, contributory fault is a tool that allows arbitral tribunals to reduce a state's international responsibility if the investor contributed to the investment loss that it suffered and it foresaw such consequence. ${ }^{16}$ This consequence must not be foreseen as an isolated event, but, rather, the investor must identify the actual causes of it in its foresight. ${ }^{17}$ This aspect of contributory fault deals with the problem of opportunism that arises from the jurisprudence from BayWa v. Spain. Effectively, it means that if the state wants to raise the defence of contributory fault to reduce its international responsibility, then its decision to stop giving the investor certain treatment must be motivated by the illegality of such treatment, otherwise it will not be an 'actual' cause.

For those cases where the state's actual causal contribution to the investment loss is the motivation to deny the investor the benefit of illegal treatment, the next question will be: should the investor have foreseen this action? The decisive factor here will be the state of the law on the legality of the treatment. For example, in cases like BayWa v. Spain where it was clear that the treatment was illegal, the conclusion will be that the investor should have foreseen it, with the result that it could be apportioned most (perhaps all) of the state's international responsibility. This possibility takes care of the problem that troubled the arbitral tribunal for BayWa v. Spain, namely that the investor could use an investment treaty to claim compensation when the state denied it the benefit of flagrantly unlawful treatment. But using contributory fault does more than solve this problem. Most promisingly, it can deliver nuanced outcomes that pay attention to the specific facts of the case. For example, consider a case where the jurisprudence is unsettled on the question of the legality of the relevant treatment. The investor's legal team notes this unsettled jurisprudence as a legal risk. Years later, (honest) courts in the host state confirm that the treatment is illegal, which then prompts the

16 See generally Anaïs Moutier-Lopet, 'Contribution to the Injury' in: James Crawford, Alain Pellet, Simon Olleson and Kate Parlett (eds), The Law of International Responsibility (Oxford: Oxford University Press 2010).

17 Martin Jarrett, Contributory Fault and Investor Misconduct in Investment Arbitration (Cambridge: Cambridge University Press 2019), 87. 
state to deny it. The investor sues in investment-treaty arbitration. This is the kind of case where the arbitral tribunal might split the international responsibility 50:50. But, imagine that the relevant investor is a start-up company with very limited funds for legal due diligence and it does not know of the legal risk. Additionally, the rule that makes the treatment illegal is a very technical one. In light of these circumstances, the arbitral tribunal might see that a 50:50 split is unfair, and rather determines that 90:10 is in order. And contributory fault gives it this possibility. The jurisprudence from BayWa v. Spain does not. It has a binary function: if the treatment is illegal, then all responsibility effectively falls on the investor.

This is a convenient point to discuss another virtue of using contributory fault, specifically that its use better respects the existing doctrine of international law. Two reasons underpin this observation. First, contributory fault is a well-recognised legal concept in international law, whereas the jurisprudence from BayWa v. Spain constitutes a new exception to the rule in Article 3 of the Articles on the State Responsibility. And, incidentally, to make this exception work, it should be expected that exceptions will have to be made to it. As an example, consider the case mentioned in section 3 where the (biased) domestic court confirms that the treatment given to the investor was illegal. Assuming that the investor can prove such bias, which it probably cannot, then would an arbitral tribunal accept this legal opinion from the court? Hopefully not. It would carve out a 'biased court' exception to the exception to the rule in Article 3. Using contributory fault avoids this complexity. It simply looks at the state of the law on the legality of the relevant treatment at the time that the investor invested and asks: in light of this law, should the investor have foreseen the investment loss that it suffered? No inquiry into the bias of a domestic court is needed. Rather, an inquiry into the state of the law is necessary, which reveals the other reason why using contributory fault better respects the existing doctrine of international law: it treats domestic law as a fact. And because domestic law is treated as a fact, the technique of using contributory fault is in complete harmony with the rule in Article 3 of the Articles on State Responsibility.

\section{Conclusion}

This analysis entails that the new jurisprudence from BayWa v. Spain should be replaced with the alternative jurisprudence. Effectively, the recommendation is that the case law of international investment law should be changed. In making that recommendation, an acknowledgement is necessary: 
the legal scholar has the luxury of observing new jurisprudential developments from the side-line, not in the heat of the action of international adjudication, and critiquing them from that vantage point. That is one of the great privileges of being a legal scholar. Naturally, however, that privilege comes with responsibility, particularly regarding the research method that is used.

In this comment, a conscious effort has been made to undertake doctrinal analysis. Some years ago, this point would not be worth mentioning, but it is feared that sometimes the value of doctrinal analysis is forgotten. It should not be. Using doctrinal analysis can make law more logical and coherent, which then pays dividends when it has to be used in broader society. This method can be contrasted with methods that use activist-leaning ideologies to recommend changes to the jurisprudence of a particular area of law. The key message is: stick to the established doctrine. It is product of centuries of hard adjudicative and scholarly labour. Legal scholars are the fortunate inheritors of this immense wealth - let us not squander it.

Martin Jarrett 